DOI: 10.14526/2070-4798-2019-14-2-60-64

\title{
Studying the effectiveness of the IX stage All-Russian Physical Sports Complex GTO (RLD) normatives fulfillment, which define physical readiness of population at the age of 50-54
}

\author{
Aleksey V. Fursov ${ }^{1 *}$, Nikolay N. Beznosko${ }^{1}$, Svetlana A. Davydova ${ }^{2}$, Nikolay I. \\ Sinyavskiy ${ }^{1}$, Nikolay N. Sinyavskiy ${ }^{1}$ \\ ${ }^{1}$ Surgut State Pedagogical University, Russia, Surgut \\ ${ }^{2}$ Nizhnevartovsk State University, Russia, Nizhnevartovsk \\ ORCID: 0000-0003-3711-2949, FursovAV@bk.ru* \\ ORCID: 00oo-0o02-5845-5580, csc@surgpu.ru \\ ORCID: 0ooo-0oo1-5619-3882,ffkis@nvsu.ru \\ ORCID: 0ooo-0oo2-1596-4385, nsin1967@yandex.ru \\ ORCID: oooo-0oo2-9623-6370, sinyavskiynik@mail.ru
}

\begin{abstract}
The aim of the research is to reveal the level of physical readiness according to the final results of the IX the stage GTO (RLD) norms fulfillment by the population of Surgut. The authors analyzed physical fitness of population at the age of 50-54 and their readiness to master normatives of "Ready for labor and defense" (RLD) complex. Research methods. Stating pedagogical experiment was held according to the results of test among 50-54 year-old people. They were registered and took part in state nornatives fulfillment of All-Russian Physical Sports Complex GTO (RLD) in the Surgut center of testing. The results according to GTO (RLD) complex were handled with the help of information system (127 respondents-70 men and 57 women). Results. Physical fitness of population analysis in Surgut showed that $10 \%$ of men at the age of 50-54 fulfilled GTO (RLD) complex normatives and got gold badges, 5,7\% got silver badge. $82,3 \%$ of men didn't manage to fulfill the normatives. Among 50-54 year-old women gold badge got $14,3 \%$ of respondents, silver badge- $7 \% .78,9 \%$ of women didn't fulfill GTO (RLD) complex normatives. The problem tests at the age group of 50-54 years-old at the IX stage among men was endurance test, among women endurance and power abilities tests. Conclusion. As a result of the held experiment the authors came to the conclusion that nowadays the most urgent problem becomes the problem of mass physical culture, health-improving and sports work forms, methods and means development among population.
\end{abstract}

Keywords: research, physical readiness, results, pedagogical experiment, center of testing, methods and means.

For citation: Aleksey V. Fursov, Nikolay N. Beznosko, Svetlana A. Davydova, Nikolay I. Sinyavskiy, Nikolay N. Sinyavskiy. Studying the effectiveness of the IX stage All-Russian Physical Sports Complex GTO (RLD) normatives fulfillment, which define physical readiness of population at the age of 50-54. The Russian Journal of Physical Education and Sport. 2019; 14(2): 52-55. DOI 10.14526/2070-4798-2019-14-2-60-64.

\section{Introduction}

Nowadays one of the main demands of GTO (RLD) complex realization among all age categories of the Russian Federation population is systematic physical exercises fulfillment [3,5]. Creation and introduction of different mechanisms of population involvement into physical culture health-improving methodologies and kinds of sport would provide successful APSC GTO (RLD) realization in the Russian Federation. It will lead to the interest increase in physical culture lessons, motor activity activation and physical and functional readiness improvement. It has a positive influence on health state level and high working capacity of a person provision $[2,4,6,7,8,9,10,11,12]$.

The results of physical readiness testing among population (Surgut) were used as the research material at the age category 50-54 years-old on the basis of GTO (RLD) complex norms. The received results handling was held using AS PSC GTO (RLD) (Automized support of physical culture and sport complex GTO) online-service [1]. 127 people took part in the research (70 men and 57 women).

\section{Results and Discussion}

During the tests fulfillment among men we 
received the following results (picture 1). In power abilities test $31,4 \%$ of respondents (22 people) received gold badge, $4,3 \%$ of respondents ( 3 people) got silver badge, $1,4 \%$ of respondents ( 1 person) got bronze badge. 44 people $(62,9 \%)$ didn't cope with power abilities test.

In endurance test among men $18,6 \%$ of respondents (13 people) got gold badge, 1,4\% of respondents ( 1 person) got silver badge. 80,0\% of respondents ( 56 people) didn't cope with endurance test.

In flexibility test $22,9 \%$ of respondents (16 people) got gold badge. $8,6 \%$ of respondents ( 6 people) got silver badge. 48 people $(68,6 \%)$ didn't cope with flexibility test.

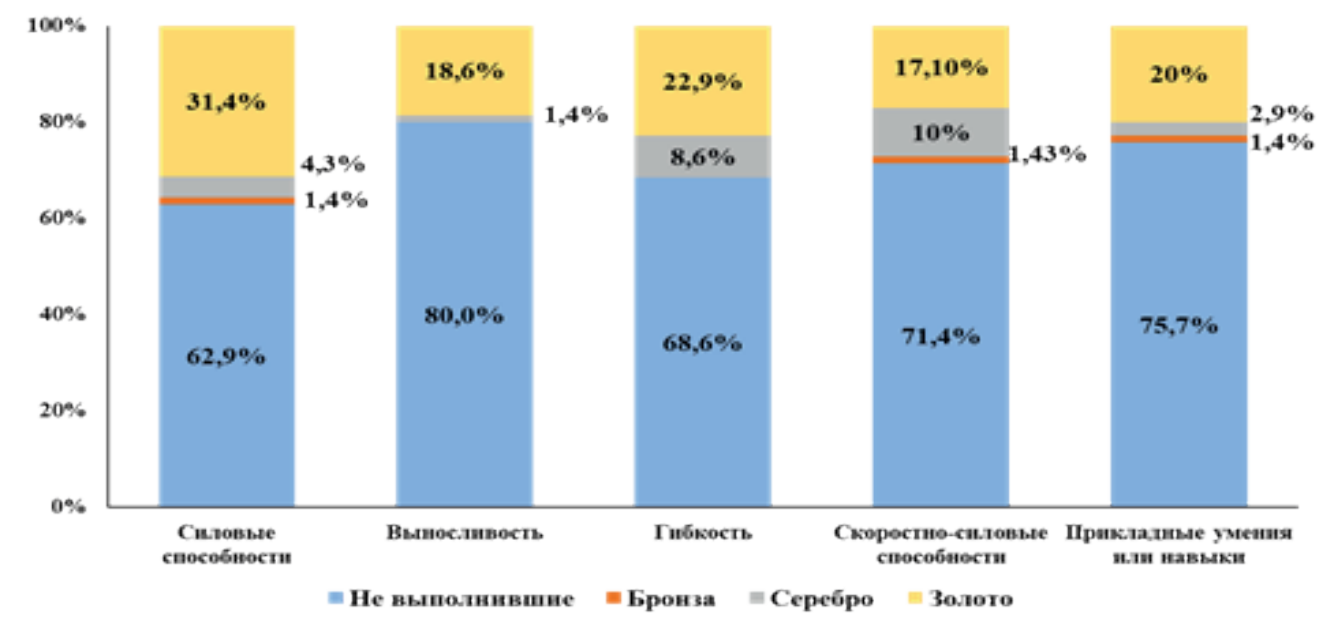

Picture 1 - The results of physical readiness among men at the age category 50-54 years-old according to IX stage of GTO (RLD) complex normatives

Силовые способности-power abilities

Выносливость-endurance

Гибкость-flexibility

Скоростно-силовые способности-speed-power abilities

Прикладные умения или навыки-applied abilities and skills

Не выполнившие-didn't cope

Бронза-bronze

Серебро- silver

Золото-gold

In speed-power abilities test $17,1 \%$ of respondents or 12 people got gold badge. Silver badge got 10,0\% of respondents or 7 people, 1 person $(1,4 \%)$ got bronze badge. 50 people $(71,4 \%)$ didn't cope with speed-power abilities test.

During the applied abilities and skills test fulfillment the results were the following: $20,0 \%$ of respondents (14 people) got gold badge, 2,9\% (or 2 people) got silver badge, $1,4 \%$ of respondents ( 1 person) got bronze badge of GTO(RLD).53 people (75,7\%) didn't cope with the test.

In tests among women the results were the following (picture 2): in power abilities test $29,8 \%$ of respondents (17 people) got gold badge, 10,5\% of respondents (6 people) - silver badge, 3,5\% (2 people) - bronze badge.

32 people $(56,1 \%)$ didn't cope with power abilities test.

In endurance test among women $22,8 \%$ of respondents (13 people) got gold badge, 1,7\% of respondents ( 1 person) got silver badge. 43 women $(75,4 \%)$ didn't cope with the test.

In flexibility test $47,4 \%$ of respondents (27 people) got gold badge. $8,7 \%$ of respondents ( 5 people) got silver badge. $1,7 \%$ of respondents ( 1 person) got bronze badge. 24 women (42,1\%) didn't cope with flexibility test.

In speed-power abilities tests $31,6 \%$ of respondents (18 people) got gold badge. Silver badge got $8,7 \%$ of respondents or 5 people and $12,3 \%$ of respondents (7 people) got bronze badge. 27 people $(47,4 \%)$ didn't cope with the test. 
In applied abilities and skills test the results were silver badge, 1,7\% of respondents or 1 woman got the following: $21,1 \%$ of respondents or 12 people got bronze badge. 42 women $(73,7 \%)$ didn't cope with gold badge, $3,5 \%$ of respondents or 2 women got the test.

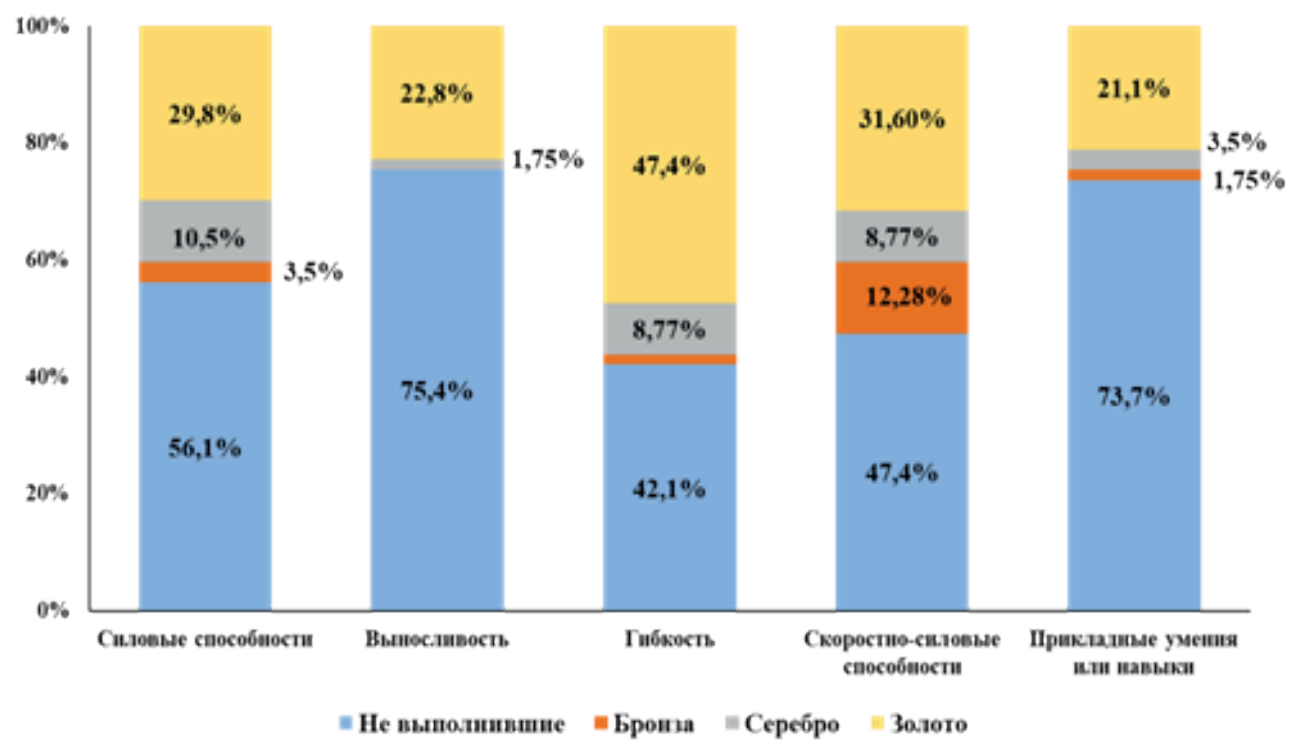

Picture 2 - The results of physical readiness among women at the age category 50-54 years-old according to IX stage of GTO (RLD) complex normatives

Силовые способности-power abilities

Выносливость-endurance

Гибкость-flexibility

Скоростно-силовые способности-speed-power abilities

Прикладные умения или навыки-applied abilities and skills

Не выполнившие-didn’t cope

Бронза-bronze

Серебро- silver

Золото-gold

\section{CONCLUSION}

Physical readiness results analysis according to IX stage of GTO (RLD) complex showed that the worst results of testing were among men at the age of 50-54 according to the kinds of tests. They define endurance level development. $80 \%$ of respondents didn't cope with this kind of test. In speed-power abilities test, applied abilities and skills test more than $70 \%$ of respondents didn't cope with the tasks. $68 \%$ of respondents didn't cope with flexibility test.

Among women there was a low level of endurance development (more than $75 \%$ of respondents didn't cope with this kind of test) and insufficient level of the main applied abilities and skills. The results of the held analysis help to actualize the questions, connected with the most effective means use for endurance development, for mastering necessary and vital applied abilities and skills.

REFERENCES
1. Beznosko N.N., Sinyavskiy N.I., Fursov A.V., Glukhova M.Y. The normatives fulfillment estimation of the VIII stage of "Ready for labor and defense" (GTO) complex among the population of the age category 40-44 years-old. Pedagogikopsikhologicheskie I medico-biologicheskie problem fizicheskoi kultury i sporta $=$ The Russian Journal of Physical Education and Sport. 2018; 13(4): 38-42 [In Russ., In Engl.].

2. Zuyrin E.A., Kurentsov V.A., Bobkova E.N., Kozlov A.A. Physical readiness state analysis among adults of Moscow region according to the results of GTO (RLD) complex realization. Vestnik sportivnoy nauki. 2018; 5: 65-70 [In Russ.].

3. Zuyrin E.A., Bobkova E.N., Morozov V.N., Polievskiy S.A. Physical activity of population as the factor of All-Russian physical culture sports complex GTO (RLD) realization in the Russian Federation in 2016-2017. Teoriya i praktika fizicheskoi kultury = 
Theory and practice of physical culture. 2018; 11: 4143 [In Russ., In Engl.].

4. Levushkin S.P., Sonkin V.D. Age-related changes of physical readiness among population in the Russian Federation according to the results of GTO(RLD) complex normatives fulfillment. Teoriya i praktika fizicheskoi kultury $=$ Theory and practice of physical culture. 2019; № 1: 89 [In Russ., In Engl.].

5. Medvedkova N.I., Zotova T.V. The attitude revelation of different population groups to GTO (RLD) complex normatives fulfillment. Humanitarian education at a technical higher educational establishment. Sbornik dokladov Vserossijskoj nauchno-prakticheskoj konferencii s mezhdunarodnym uchastiem [The collection of reports of All-Russian scientific-practical conference with the international participation]. 2017: 845850.

6. Fursov A.V., Sinyavskiy N.I., Vlasov V.V. Physical readiness of population to realize the VIII stage GTO (RLD) complex normatives. Fizicheskays kultura: vospitanie, obrazovanie, trenirovka. 2019; 2: 65-66 [In Russ.].

7. Khromin E.V. All-Russian physical culture and sport GTO (RLD) complex managing at a

municipal level. Teoriya i praktika fizicheskoi kultury $=$ Theory and practice of physical culture. 2019; 1: 3-5 [In Russ., In Engl.].

8. Beaton A.A., Funk D.C., Alexandris K. Operationalizing a theory of participation in physical active leisure. Journal of Leisure Research. 2009; 41: 177-203.

9. Dawson P., Downward P. The relationship between participation in sport and sport volunteering: An economic analysis. International Journal of sport Finance. 2013; 8: 75-92.

10. Downward P., Rasciute S. Does sport make you happy? An analysis of the well-being derived from sports participation. International Review of applied Economics. 2011; 25: 331-348. DOI: 10.1080/02692171.2010.511168.

11. Federico B., Falese L., Marandola D., Capelli G. Socioeconomic differences in sport and physical activity among Italian adults. Journal of Sports Sciences. 2013; 31: 451-458.

12. Hovemann G., Wicker P. Determinants of sport participation in the European Union. European Journal of Sport and Society. 2009; 6: 5159.

Submitted: 23.05 .2019

\section{Author's information:}

Alexey V. Fursov - Candidate of Pedagogics, Associate Professor, Surgut State Pedagogical University, 62840o, Russia, Surgut, Artema str., House 9, e-mail: FursovAV@bk.ru

Nikolay N. Beznosko - Candidate of Pedagogics, Associate Professor, Surgut State Pedagogical University, 62840o, Russia, Surgut, Artema str., House 9, e-mail: csc@surgpu.ru

Svetlana A. Davydova - Candidate of Pedagogical Sciences, Associate Professor, Nizhnevartovsk State University, 628605, Russia, Nizhnevartovsk, Lenina str., House 2, e-mail: ffkis@ nvsu.ru

Nikolay I. Sinyavskiy - Doctor of Pedagogics, Professor, Surgut State Pedagogical University, 62840o, Russia, Surgut, Artema str., House 9, e-mail: nsin1967@yandex.ru

Nikolay N. Sinyavskiy - Post-graduate, Surgut State Pedagogical University, 62840o, Russia, Surgut, Artema str., House 9, e-mail: sinyavskiynik@mail.ru 